\title{
Experiments to predict the response of thematic mapper bands 3, 4 and 5 to grass drought
}

\author{
M. A. MULDERS \& A. VAN LOGCHEM \\ Department of Soil Science and Geology, Wageningen Agricultural University, P.O.Box, 37, \\ NL 6700 AA Wageningen, Netherlands
}

Received 28 March 1991; accepted 1 May 1991

\begin{abstract}
Samples of sods taken at different locations showed a range in grass and soil types. During a dry-up period in the laboratory, reflectance measurements were carried out and moisture contents of grass and soil were estimated. The soil moisture contents were converted to $\mathrm{pF}$ values. The narrow band values of the laboratory measurements on reflectance were added to compose broad Thematic Mapper bands. Multiple linear regression on the experimental results produced equations with grass moisture, soil moisture and $\mathrm{pF}$ as dependent variables. These variables could be estimated from reflectance values in the TM bands 3,4 and 5 with respective standard errors of $13.8-16.0 \%, 8.5 \%$ and $0.1 \%$. The pattern of TM satellite data of grassland at one specific acquisition date revealed that it is very likely that remote sensing data may be used to detect drought phenomena, be it that field observations are still required.
\end{abstract}

Keywords: remote sensing, grass drought, Thematic Mapper

\section{Introduction}

Multispectral remote sensing either by aerial photography (Clevers, 1986, 1988) or by satellite scanning (Mulders, 1987) is a valuable tool for distinguishing arable crops and for estimating crop characteristics. Thematic Mapper (TM) satellite data may be used in an adequate way for this purpose (Epema, 1987). The weather conditions in the Netherlands are such that the chance on cloud-free satellite imagery is moderate. The availability of TM imagery in the Netherlands has been estimated on 0.65 cloud-free summer image per year as an average for complete coverage of the Netherlands (van der Laan, 1989); the chance on partial coverage by cloud-free imagery is higher.

The TM satellite has 6 bands in the $450-2350 \mathrm{~nm}$ range of wavelengths (electromagnetic spectrum), each band having a ground resolution cell of $30 \mathrm{~m} \times 30 \mathrm{~m}$. For the question whether TM data can be used for detection of grass drought, the spectral response of vegetation to drought is a key item. The reflectance in the visible (400-700 nm) is a function of grass density, green grass coverage and of the chlorophyll content of the leaves. As grass dries up, its structure changes. Wilting results 
in a slightly lower surface area of leafs exposed to solar irradiance. A weak decrease in absorption by chlorophyll and consequent weak increase of reflectance of visible radiation may be expected. Eventually the loss of vigor leads to a reduction in the chlorophyll content and to unmasking of yellow pigments (Colwell, 1970) with, consequently, an important increase in green and red reflectance. The near infrared $(700-1300 \mathrm{~nm})$ reflectance, however, reduces as vegetation becomes drier (Paltridge et al., 1988). The reflection of near infrared in this wavelength range is taking place at cell walls, that is at the transition of air and walls (de Boer, 1990). The amount of such places exposed to the irradiance determines the degree of near infrared reflectance. As a result, this reflectance is considered to be a function of the grass canopy structure, which may be characterized by grass density and green grass coverage. It may be expected that in drying up the relationship is different for tree crops and crops with long stems in general, than it is for grass and cereals with short blades. In this connection, the impact of drought will be less drastic for these crops since the blades do not hang freely downwards. The near infrared range between 1300 and $2500 \mathrm{~nm}$ contains important water absorption bands. Decrease in moisture content of plant leaves results in increase of reflectance in these bands (de Boer, 1990).

Taking into account these spectral properties and the results of others (Bunnik, 1978; Richardson et al., 1983), the following TM bands have been selected for this research:

- Band 3 : 630-690 $\mathrm{nm}$;

- Band 4 : 760-900 nm;

- Band 5 : 1555-1750 nm.

Band 3 is regarded to represent the visible range and indicates yellowing of vegetation as a result of drought or it indicates the presence of dry hay.

Band 4 is an indicator of the surface area of cell walls exposed to the irradiance, while band 5 responses most to the moisture content of vegetation, this band being located nearby a water absorption band at $1900 \mathrm{~nm}$ (Mulders, 1987).

Reflectance measurements at sod samples were done in the laboratory to study the relationship between drought indicators (grass and soil moisture content, $\mathrm{pF}$ ) and the simulated TM bands selected for this study. Other studies indicated the high correlation of $\mathrm{pF}$ with reflectance of bare soil surfaces (Janse et al., 1976). The wellknown relationship between $\mathrm{pF}$ and plant growth provides a base for the expectation that the reflectance of grass shows high correlation with this measure. Average experimental reflectance values were used to explain spectral patterns of remotely sensed TM data acquired after a dry period. Measurements on soil moisture in drying up the sods were studied to evaluate the effect of soil type on available water after climatic drought.

\section{Materials and methods}

Samples of sods (size $60 \times 30 \mathrm{~cm}$, height $10 \mathrm{~cm}$ ) were taken at different locations. In the laboratory, soil analyses were done and the moisture contents of soil and vegetation were determined (as average of 2 measurements) at different stages of 
dry-up. The values on soil moisture content were converted to $\mathrm{pF}$ values.

The reflectance of the samples was estimated at each dry-up stage with the NIWARS-spectrometer constructed by the Laboratories of the Institute of Applied Physics (TNO, Delft). This apparatus measured the reflectance factor ( $\%$ ) as a function of wavelength for the $361-2360 \mathrm{~nm}$ range with bandwith of $17 \mathrm{~nm}, 25 \mathrm{~nm}$ and $42 \mathrm{~nm}$ using Si and PbS detectors (Bunnik, 1978; Clevers, 1986). Since the measurements were performed in the laboratory, an aperture of $2.5 \mathrm{mrad}$ was used, which resulted in an area of $10 \times 10 \mathrm{~cm}$ on the ground. Average values of three measurements at different spots were used to obtain estimated reflectance values of the samples. The reflectance factors of the narrow bands used in the spectrometer were added to compose (average) reflectance factors valid for the TM bands 3, 4 and 5 .

The correlation coefficients of two measurements on the same spot, but at different times, were respectively: 0.99 (band 3), 0.99 (band 4) and 0.89 (band 5). The equipment appeared to be less accurate in band 5 .

\section{Description of samples}

Sod and soil samples were taken at three locations in the north-eastern part of the Netherlands: Hondsrug, Zuidlaarder Lake border and Hunze valley. Data of these samples are given in Tables 1 and 2 (soil classification according to Stiboka, 1977).

Lolium perenne and Poa annua were the dominant grass types, which often occurred in combination or mixed with other grass types (Table 1).

Two main subdivisions of soils could be made: sandy hydro-earth soils with a moderate content of organic matter and very dark (greyish) brown topsoils at one

Table 1. Description of grass samples 13-07-87.

\begin{tabular}{lllll}
\hline $\begin{array}{l}\text { Sample } \\
\mathrm{Nr}\end{array}$ & Location & Grass types & $\begin{array}{l}\text { Vegetation } \\
\text { coverage } \\
(\%)\end{array}$ & $\begin{array}{l}\text { Green } \\
\text { vegetation } \\
\text { coverage } \\
(\%)\end{array}$ \\
1 & & & 76 \\
2 & Hondsrug & Lolium perenne & 80 & 67 \\
3 & Hondsrug & Lolium perenne & 95 & 15 \\
4 & Hondsrug & Lolium perenne & $50-100^{*}$ & 30 \\
5 & Hondsrug & Lolium perenne & 60 & 86 \\
6 & Border Zuidlaarder Lake & Poa annua & 90 & 78 \\
7 & Poa trivialis & & 32 \\
8 & Border Zuidlaarder Lake & Elytrigia repens & & 57 \\
9 & Hunze valley & Lolium perenne & 45 & 32 \\
& Hunze valley & Lolium perenne & 95 & 97 \\
\hline
\end{tabular}

* $50 \%$ green grass coverage; $100 \%$ if dry matter is included. 
Table 2. Data of soil samples $(0-10 \mathrm{~cm})$.

\begin{tabular}{|c|c|c|c|c|c|c|c|}
\hline \multirow{2}{*}{$\begin{array}{l}\text { Sample } \\
\mathrm{Nr}\end{array}$} & \multirow{2}{*}{$\begin{array}{l}\text { Dutch soil } \\
\text { classification }\end{array}$} & \multirow{2}{*}{$\begin{array}{l}\mathrm{pH} \\
\mathrm{KCl}\end{array}$} & \multirow{2}{*}{$\begin{array}{l}\text { OM } \\
(\%)\end{array}$} & \multicolumn{3}{|c|}{ Soil texture $(\%)$} & \multirow{2}{*}{$\begin{array}{l}\text { Munsell } \\
\text { colour of } \\
\text { matrix }\end{array}$} \\
\hline & & & & $2000-50 \mu \mathrm{m}$ & $50-2 \mu \mathrm{m}$ & $<2 \mu \mathrm{m}$ & \\
\hline $1 / 2$ & Sandy hydro-earth soils & 5 & 5.4 & 66.5 & 29.6 & 3.9 & $10 \mathrm{YR} 2 / 2$ \\
\hline $3 / 4$ & Sandy hydro-earth soils & 3.9 & 4.0 & 82.6 & 13.7 & 3.7 & $10 Y R 3 / 2$ \\
\hline $5 / 6$ & Weide peat soils & 4.3 & 28.6 & 38.9 & 51.1 & 10.0 & $7.5 \mathrm{YR} 3 / 2$ \\
\hline 7 & Koop peat soils & 4.9 & 20.3 & 66.1 & 31.4 & 2.5 & $7.5 \mathrm{YR} 3 / \mathrm{C}$ \\
\hline 8 & Broek earth soils* & 4.9 & 40.2 & 38.2 & 57.8 & 4.0 & $7.5 \mathrm{YR} 2 / 0$ \\
\hline 9 & Meer peat soils & 4.8 & 33.0 & 36.1 & 53.0 & 10.9 & $7.5 \mathrm{YR} 3 / 2$ \\
\hline
\end{tabular}

* Peaty earth soils.

hand (Nrs 1-4, Table 2) and peat soils or peaty earth soils with dark brown, very dark grey or black topsoils at the other hand (Nrs 5-9, Table 2). The first are welldrained soils situated on the Hondsrug ridge, the latter are poorly and very poorly drained soils of the Hunze valley and Zuidlaarder Lake border.

The $\mathrm{pF}$ curves of different topsoils (Figure 1) supported this subdivision. The

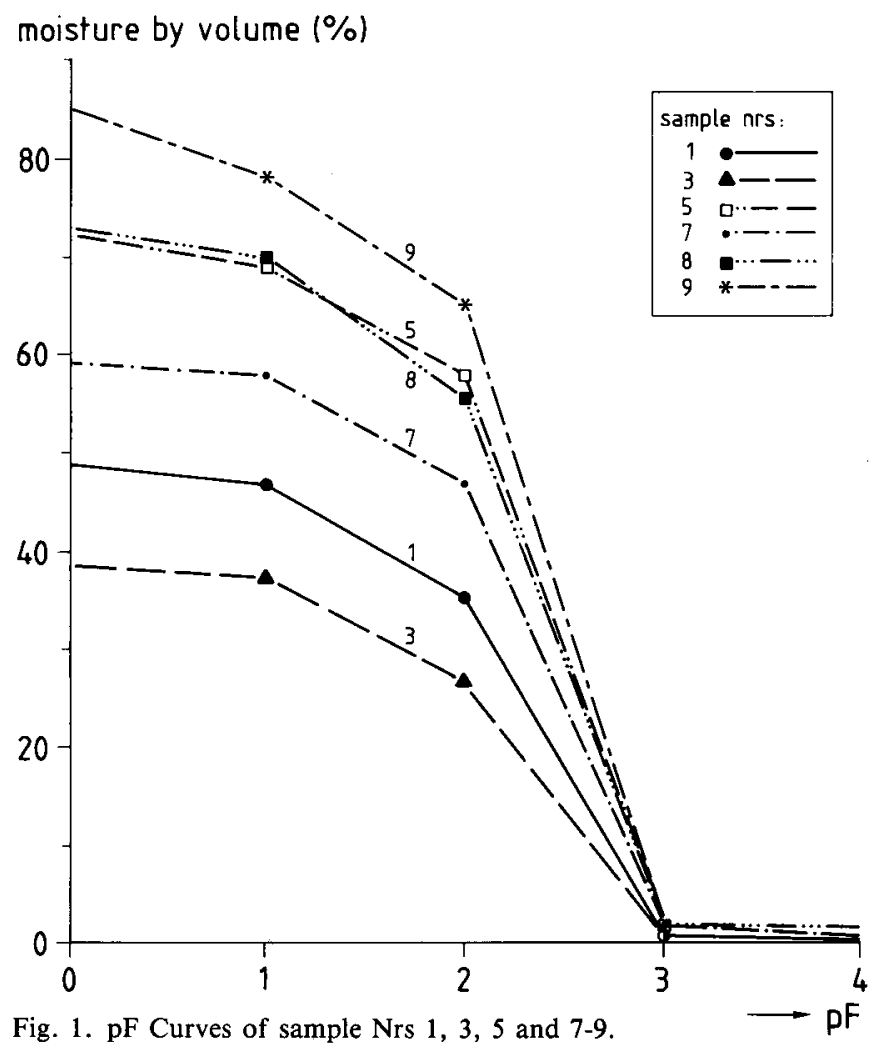

Netherlands Journal of Agricultural Science 39 (1991) 
hydro-earth soils (Nrs 1 and 3) showed relatively low pF values, the peat soils (Nrs 5,8 and 9) relatively high $\mathrm{pF}$ values at the same moisture content. The Koop peat soils ( $\mathrm{Nr} 7$ ) with a somewhat lower organic matter content than the other peat or peaty earth soils were intermediate in this respect. The data on bulk density (Table 4) resulted in a similar subdivision.

\section{Results and interpretation}

The effect of drying up the soil of sods and the grass foliage is shown by moisture content at different stages in Tables 3 and 4 . The initial soil moisture content of peat and peaty earth soils was in 3 out of 5 cases (Table 4: sample Nrs 5,7 and 8) much higher than that of the sandy hydro-earth soils (Table 4: sample Nrs 2, 3 and 4). After a period of $21 / 2$ weeks (up to $31 / 7$ in Table 4), these soils had (in 4 out of 5 cases) still a reasonable moisture content (equal to or more than $1 / 2$ of the initial

Table 3. Moisture content (\% by weight) of grass foliage samples during dry up period in 1987.

\begin{tabular}{|c|c|c|c|c|c|}
\hline \multirow{2}{*}{$\begin{array}{l}\text { Sample } \\
\mathrm{Nr}\end{array}$} & \multicolumn{5}{|c|}{ Grass moisture ( $\%$ by weight) at date } \\
\hline & $14 / 7$ & $17 / 7$ & $23 / 7$ & $31 / 7$ & $14 / 8$ \\
\hline 1 & & 65 & $\begin{array}{l}68 \\
21^{*}\end{array}$ & $\begin{array}{l}58 \\
16^{*}\end{array}$ & 21 \\
\hline 2 & 77 & 82 & 32 & 20 & 13 \\
\hline 3 & $37 * *$ & $30^{* *}$ & 28 & 15 & 25 \\
\hline 4 & 61 & 39 & 21 & 16 & \\
\hline 5 & 73 & 75 & 63 & 53 & 37 \\
\hline 6 & 65 & 53 & 29 & 18 & 16 \\
\hline 7 & 74 & 80 & 61 & 60 & 19 \\
\hline 8 & 75 & 68 & 42 & 30 & 16 \\
\hline 9 & 64 & 72 & 53 & 22 & 18 \\
\hline
\end{tabular}

* Upper value green grass, lower value hay.

** $14 / 7$ grass + hay, $17 / 7$ grass only.

Table 4. Bulk density values and soil moisture content ( $\%$ by volume) during dry up period.

\begin{tabular}{|c|c|c|c|c|c|c|}
\hline \multirow{2}{*}{$\begin{array}{l}\text { Sample } \\
\mathrm{Nr}\end{array}$} & \multirow{2}{*}{$\begin{array}{l}\text { Bulk } \\
\text { density }\end{array}$} & \multicolumn{5}{|c|}{ Soil moisture ( $\%$ by volume) at date } \\
\hline & & $14 / 7$ & $17 / 7$ & $23 / 7$ & $31 / 7$ & $14 / 8$ \\
\hline 1 & 1.37 & & 12 & 14 & 8 & 4 \\
\hline 2 & 1.37 & 21 & 19 & 8 & 7 & 4 \\
\hline 3 & 1.63 & 16 & 11 & 8 & 5 & 3 \\
\hline 4 & 1.63 & 10 & 8 & 5 & 3 & 3 \\
\hline 5 & 0.69 & 46 & 37 & 26 & 23 & 11 \\
\hline 6 & 0.69 & 8 & 9 & 7 & 7 & 4 \\
\hline 7 & 1.03 & 37 & 33 & 24 & 22 & 10 \\
\hline 8 & 0.70 & 37 & 29 & 26 & 24 & 16 \\
\hline 9 & 0.28 & 20 & 15 & 13 & 13 & 8 \\
\hline
\end{tabular}


moisture content) but available at relatively high $\mathrm{pF}$ value ( $\mathrm{pF}$ equal to or more than 2.7). In most sods, there was still some grass growth in this stage. The degree of soil dry-up was stronger in the sandy hydro-earth soils. The moisture content in these soils was reduced after $21 / 2$ weeks up to about $1 / 3$ of the initial soil moisture content and $\mathrm{pF}$ values were such that the water was not well available for grass growth.

The moisture content of grass foliage (Table 3) showed the same tendency. In 3 out of 5 cases (sample Nrs 5, 7 and 8), the values for grass foliage of sods of peat and peaty earth soils were reduced after $21 / 2$ weeks on an average base to $64 \%$ of the initial moisture content but with a high range in values. Two weeks later (Table 3,14/8), the drought was severe for these samples, the moisture content of foliage being reduced to an average of $1 / 3$ of the initial value. This stage was reached earlier for 2 samples (Nrs 6 and 9) of the peat and peaty earth soils. The samples (Nrs 2 and 4) of sandy hydro-earth sods showed a strong reduction in moisture content of grass foliage after $21 / 2$ weeks, namely up to about $1 / 4$ of the inital value; the samples ( $\mathrm{Nrs} 1$ and 3 ) with original cover by hay deviated.

A selection of samples was made to obtain a set with uniformity in initial moisture content of grass foliage $(>64 \%$, Table 3 ) and original vegetation coverage $(>80 \%$, Table 1). This sample set was used to study the influence of grass type on reflectance (Figure 2). It appeared that no differentiation was possible between the three main grass types. Most of the variation in the bands 3 and 4 could be explained by the green vegetation coverage (\%), which indicates the condition of foliage. A high percentage (sample Nrs 1, 5 and 6) implies a low reflectance in band 3 (except for sample 6 with Elytrigia repens) and high reflectance in band 4, while a low percentage means the opposite (sample Nrs 8 and 9). The samples arranged according to their reflectance values in band 5 provided from high to low: $9,5,1,8,6$. This arrangement is not well in agreement with the green vegetation coverage but more with (total) vegetation coverage, the samples 6 and 8 having the highest values. Only the high (simulated TM band) value of sample $\mathrm{Nr} 9$ may be explained by its very low green vegetation coverage. Altogether, the data provide evidence for the hypothesis, that the simulated TM band values represent physiology more than grass type.

Figure 3 represents the reflectance in the simulated TM bands of dry soil surfaces which were obtained by removal of vegetation at the end of the drying up period. The two main subdivisions of soils could be distinguished (sample Nrs 1-4 and 5-9); the peaty earth soils with the darkest colour and highest organic matter content ( $\mathrm{Ta}$ ble 2) had the lowest reflectance in all TM bands.

In Table 5, correlation coefficients of the simulated values of TM bands 3, 4 and 5 with grass moisture, soil moisture and $\mathrm{pF}$ are given for two groups of samples:

A. Sod samples with original vegetation coverage $>80 \%$.

B. Sod samples with original vegetation coverage $45-60 \%$.

A number of conclusions could be drawn from these data:

- TM band 3 showed a low correlation with TM bands 4 and 5 in sample set A; there was hardly any correlation in this sample set between the bands 4 and 5;

- TM band 3 showed hardly any correlation with TM band 4 and a low correlation with TM band 5 in sample set B; 


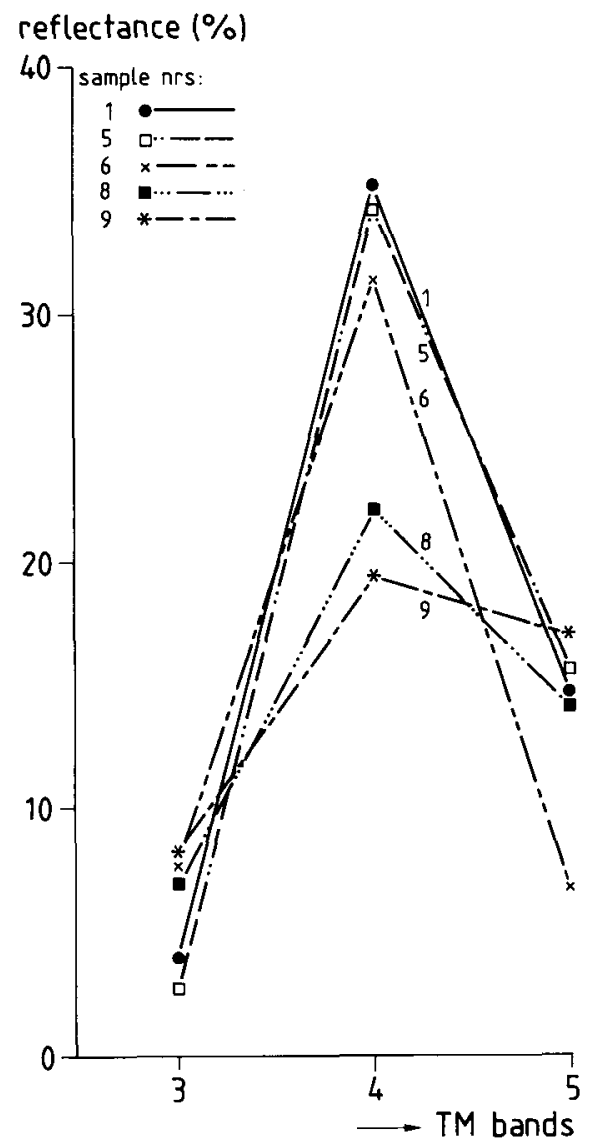

Fig. 2. Reflectance in TM bands 3, 4 and 5 measured in the laboratory of grass with uniform moisture content and coverage. Legend:

grass type coverage $(\%)$

Lolium perenne Poa annua a.o. Elytrigia repens Lolium perenne a.o. Lolium perenne a.o.

- the highest correlation of moisture indicators and TM bands was reached for grass moisture with TM band 5 in sample set $A$; soil moisture and pF versus $T M$ 3 had the highest score in sample set B;

- sample set B produced other relationships between TM band reflectance and moisture indicators, i.e. there was hardly any or very low correlation between band 5 and these indicators.

The data of Table 5 were used in making decisions on promising combinations of TM bands for estimation of the dependent variables (grass moisture, soil moisture and $\mathrm{pF}$ ): 


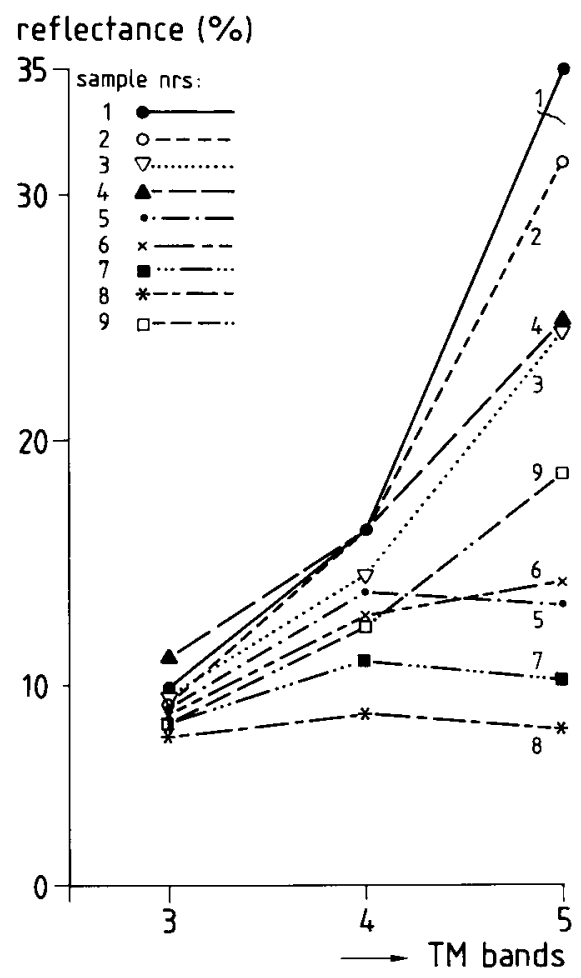

Fig. 3. Reflectance in TM bands 3, 4 and 5 measured in the laboratory of sod samples after removal of vegetation at end of dry-up period.

- bands with $\mathrm{R}$ equal to or higher than 0.40 were selected, this value was considered as the minimum linear correlation, which was acceptable;

- subsequently, the two bands with highest $\mathrm{R}$ values were selected.

Multiple linear regression was done with the selected data; the results are given in Table 6. The multiple $R$ of regression appeared to be higher than the $R$ values of individual bands with the moisture indicators, except for one case where it was equal. The adjusted $R$ square values were taken as a measure for goodness of fit of the regression models. Only those equations of multiple regression with a goodness of fit represented by adjusted $R$ square of 0.54 or more are given in Table 7 . In this way, the linear regression equations with best significance level of $F$ were selected with the exeption of set B having higher values than the one dropped from set A (sm versus bands 3 and 5). The $F$ values were highest for sample set A with relatively high $\mathrm{N}$. The standard errors indicated in Table 7 are a measure on accuracy of the regression model. Grass moisture could be estimated in sample set A with an average standard error of $14.3 \%$ and the $\mathrm{pF}$ value with a standard error of 0.1 with respective coefficients of variation of $30 \%$ and $4 \%$. The two equations on grass moisture of sample set $\mathbf{B}$ produced less accurate relationships (average standard error 15.9). Soil moisture could be estimated in this sample set with a standard error of 8.5 . 
Table 5. Correlation coefficients $(R)$ of experimental data. A. Measurements at samples with original vegetation coverage of more than $80 \%$ (samples 1, 2, 5, 6, 8 and 9). B. Measurements at samples with original vegetation coverage between 45 and $60 \%$ (samples 4 and 7 ).

\begin{tabular}{llllrrrr}
\hline $\begin{array}{l}\text { Sample } \\
\text { set }\end{array}$ & var & $N$ & sm & pF & TM3 & TM4 & TM5 \\
A & & & & & & \\
& gm & 26 & 0.67 & -0.79 & -0.67 & 0.51 & -0.78 \\
& sm & 26 & & -0.88 & -0.48 & 0.34 & -0.64 \\
& pF & 21 & & & 0.73 & -0.61 & 0.75 \\
& TM3 & 26 & & & & -0.70 & 0.69 \\
& TM4 & 26 & & & & & -0.32 \\
B & gm & 9 & 0.87 & -0.92 & 0.46 & 0.46 & -0.40 \\
& sm & 9 & & -0.99 & -0.77 & 0.32 & -0.44 \\
& pF & 5 & & & 0.78 & -0.68 & 0.14 \\
& TM3 & 9 & & & & -0.32 & 0.76 \\
& TM4 & 9 & & & & & 0.10 \\
\hline
\end{tabular}

Abbreviations: $\mathrm{gm}=$ grass moisture $(\%), \mathrm{sm}=$ soil moisture $(\%)$, var $=$ variables, $N=$ number of measurements (each measurement $=$ average of 3 ).

Table 6. Correlation coefficients $(R)$, adjusted $R$ square and $F$ values of multiple regression. $F=$ mean square regression/mean square residual.

\begin{tabular}{lllllll}
\hline $\begin{array}{l}\text { Sample } \\
\text { set }\end{array}$ & $\begin{array}{l}\text { Dependent } \\
\text { variable }\end{array}$ & TM bands & $\begin{array}{l}\text { Multiple } \\
R\end{array}$ & $\begin{array}{l}\text { Adjusted } \\
R \text { square }\end{array}$ & $F$ & $\begin{array}{l}\text { Significance } \\
\text { level }\end{array}$ \\
& & & & & $F$ \\
A & gm & $3,4,5$ & 0.83 & 0.65 & 16.71 & 0.0000 \\
& gm & 3,5 & 0.81 & 0.65 & 21.33 & 0.0000 \\
& sm & 3,5 & 0.64 & 0.36 & 8.04 & 0.0023 \\
& pF & $3,4,5$ & 0.86 & 0.68 & 15.74 & 0.0000 \\
& pF & 3,5 & 0.83 & 0.65 & 19.23 & 0.0000 \\
B & gm & $3,4,5$ & 0.86 & 0.59 & 4.82 & 0.0615 \\
& gm & 3,4 & 0.83 & 0.58 & 6.51 & 0.0314 \\
& sm & 3,5 & 0.81 & 0.54 & 5.67 & 0.0414 \\
& pF & 3,4 & 0.83 & 0.36 & 2.15 & 0.3176 \\
\hline
\end{tabular}

Abbreviations: see Table 5.

The heterogeneity of grass foliage in the sod samples, the size of the measuring unit, as well as the limited number of samples for estimation of grass and soil moisture in the laboratory experiment, induced errors which may be smaller with more samples of sods in the field covering large areas and larger samples for measurement of reflected radiance such as those of the TM satellite $(30 \mathrm{~m} \times 30 \mathrm{~m})$. At the time being, however, measurements on grass moisture and soil pF values made at the time of TM acquisition are not available. Therefore, it is only possible to compare remotely sensed TM data patterns of the bands 3, 4 and 5 with the data from the laboratory experiment, described in this paper. This is done for one set of TM 
Table 7. Equations multiple regression with relatively high adjusted $R$ square and $F$ values.

\begin{tabular}{|c|c|c|c|}
\hline $\begin{array}{l}\text { Sample } \\
\text { set }\end{array}$ & $\begin{array}{l}\text { Dependent } \\
\text { variable }\end{array}$ & Equation & $\begin{array}{l}\text { Standard } \\
\text { error }\end{array}$ \\
\hline \multirow[t]{4}{*}{ A } & gm & $0.36(\mathrm{DN}$ bd 3$)+0.99(\mathrm{DN}$ bd 4$)-1.53(\mathrm{DN}$ bd 5$)+49.62$ & 13.8 \\
\hline & gm & $-1.97(\mathrm{DN}$ bd 3) $-1.32(\mathrm{DN}$ bd 5) +87.39 & 14.5 \\
\hline & $\mathrm{pF}$ & $9.34 \mathrm{E}-03(\mathrm{DN}$ bd 3$)-0.01(\mathrm{DN}$ bd 4$)+0.01(\mathrm{DN}$ bd 5$)+2.63$ & 0.1 \\
\hline & $\mathrm{pF}$ & $0.03(\mathrm{DN}$ bd 3$)+0.01(\mathrm{DN}$ bd 5$)+2.23$ & 0.1 \\
\hline \multirow[t]{3}{*}{ B } & gm & $-7.41(\mathrm{DN}$ bd 3$)+0.35(\mathrm{DN}$ bd 4$)+0.77(\mathrm{DN}$ bd 5$)+74.16$ & 15.8 \\
\hline & gm & $-4.82(\mathrm{DN}$ bd 3) $+1.21(\mathrm{DN}$ bd 4$)+52.09$ & 16.0 \\
\hline & sm & $-3.56(\mathrm{DN}$ bd 3$)+0.33(\mathrm{DN}$ bd 5$)+34.62$ & 8.5 \\
\hline
\end{tabular}

Abbreviations: see Table 5.

data in Figure 4. Figure $4 a$ shows the average reflectance data of the samples of the experiment arranged according to their grass moisture contents. Figure $4 \mathrm{~b}$ and $4 \mathrm{c}$ show the average DNs of TM data of August 1982 (acquired after a dry period) of grassland in two areas: Hondsrug (Figure 4b) and Zuidlaarder Lake and Hunze Valley (Figure 4c). The TM data were arranged according to classification of the DNs in band 3 (low, moderate, high and very high DN; DN = Digital Number). Thus, groups came to existence which produced a pattern of average DNs in the three TM bands which was very similar to the pattern based on the average reflectance values of the experimental data: high DNs in band 3 were associated with low DNs in band 4 and with high DNs in band 5 and vice versa.

\section{Conclusions and discussion}

The simulated TM band 3 showed low correlation with the simulated TM bands 4 and 5 in the experiment on dry-up of sods with high original vegetation coverage (sample set A); the simulated TM bands 4 and 5 showed hardly any correlation in this sample set (Table 5). The laboratory reflectance measurements provide evidence for the hypothesis that the reflectance in the TM bands 3, 4 and 5 is related more to physiology of the grass cover than to grass type, at least for the types studied in the experiment. The results on multiple regression of the experimental data of sample set A with high vegetation coverage (Table 7) indicated the value of TM bands 3 and 5 for detection of grass drought. The inclusion of band 4 did not or did only slightly increase accuracy. This was also supported by the relatively low correlation coefficients of this band with the moisture indicators (Table 5). Apparently, the statement in the introduction about the specific behaviour of grass is true: grass drought normally results in increase of band 3 reflectance (yellowing) and of band 5 reflectance, but it does not produce in every case a low reflectance in band 4 . However, taking averages of many samples, grass drought ultimately produces an 

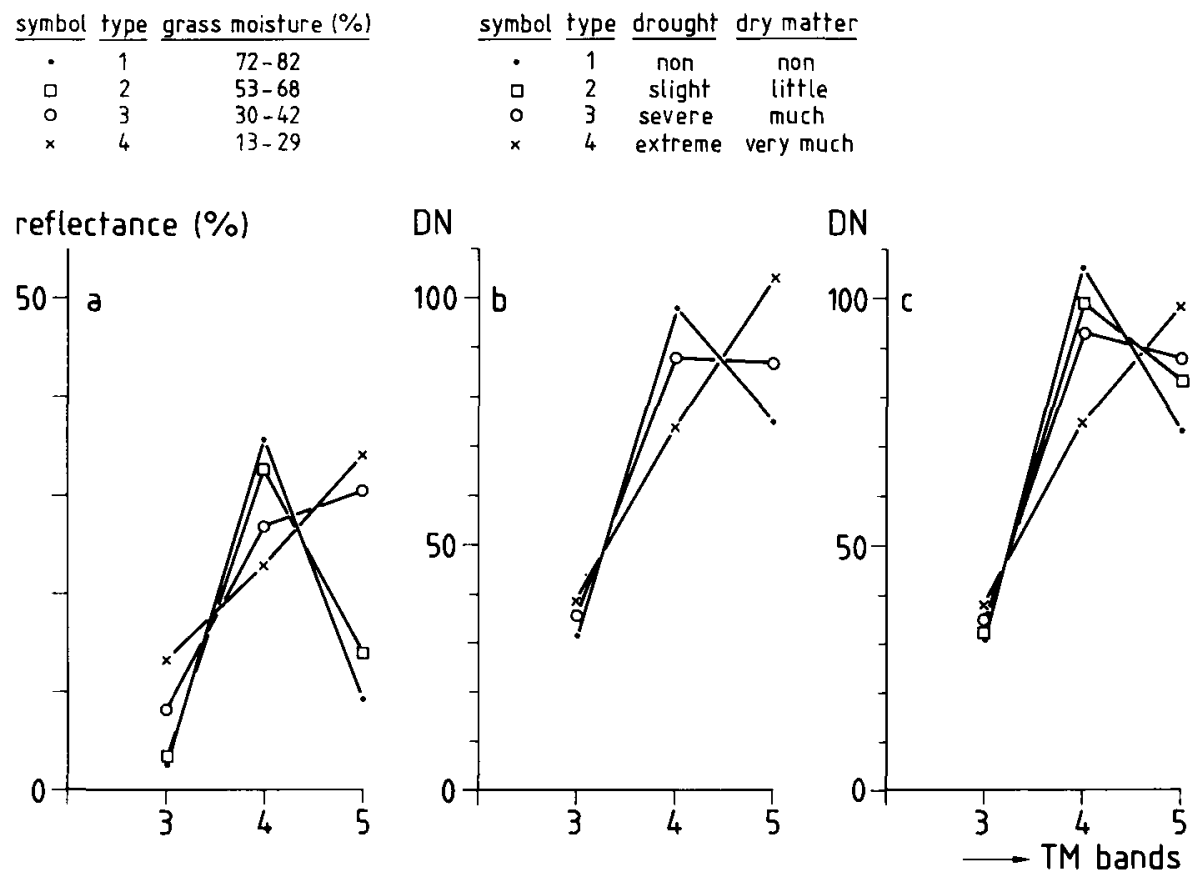

Fig. 4. Experimental average reflectance data of laboratory-simulated TM bands (a) and average DN of real TM bands 3, 4 and 5 for grassland in the Hondsrug area (b) and Zuidlaarder Lake + Hunze valley (c).

average lower leaf area and thus lower average value of band 4 (Figure 4a).

The statement is valid for grassland with high coverage. In sample set B with low grass coverage, the simulated TM band 5 proves to be a poor guide probably due to the dry condition of the upper millimetres of soil. The correlation coefficient of band 4 with grass moisture is equal to that of band 3 and with $\mathrm{pF}$, its score is relatively high. Besides the effect of direct measurement of the soil surface, the impact of drought results at low grass coverage in an 'overall' reduction of leaf area since blades hang more freely downwards and consequently the reflectance in band 4 is (overall) reduced.

The patterns found in TM digital data, which were very similar to those of the experiment (Figure 4), are promising for application of TM in grass drought research. It should be noticed, however, that it is impossible to estimate from remote distance whether the type of curve is caused by drought or the presence of dry hay on the land. At times with drought and TM overpass, the location and condition of hay land should therefore be estimated and reference data on condition of pasture have to be acquired. Field measurements on reflectance and laboratory measurements of moisture indicators should be carried out to enable quantative comparison. Accurate estimates on grass moisture contents cannot be expected by only using TM data with $30 \mathrm{~m} \times 30 \mathrm{~m}$ ground resolution, though it may be possible 
that TM data of pure samples, that is in the central part of grass plots, produce a better relationship between reflected radiance and grass moisture than the spectrometer and sample size used in this research, since the TM has a more suitable ground resolution cell for this purpose. According to the experimental results, $\mathrm{pF}$ values of soil could be estimated from reflectance values in TM bands 3 and 5 with a standard error of 0.1 (Table 7), which means that it may be expected possible to relate drought phenomena, evident from TM data and field observations, with this physical soil property. Sods on peat and peaty earth soils were found to be less sensitive to the effect of climatic drought than those on sandy hydro-earth soils.

\section{Acknowledgements}

Thanks are due to Mr W. J. Ackerman for soil physical laboratory measurements, to Dr J. G. P. W. Clevers for his critical remarks on the manuscript and P. G. M. Versteeg for drawing.

\section{References}

Bunnik, N. J. J., 1978. The multispectral reflectance of shortwave radiation by agricultural crops in relation with their morphological and optical properties. Doctoral Thesis, Wageningen Agricultural University, $176 \mathrm{pp}$.

Clevers, J. G. P. W., 1986. Application of remote sensing to agricultural field trials. Doctoral Thesis, Wageningen Agricultural University, $227 \mathrm{pp}$.

Clevers, J. G. P. W., 1988. Multispectral aerial photography as a supplemental technique in agricultural research. Netherlands Journal of Agricultural Science 36: 75-90.

Colwell, R. N., 1970. Application of remote sensing in agriculture and forestry. In: Remote Sensing With Special Reference to Agriculture and Forestry, p. 164-223. National Academy of Sciences, Washington DC.

De Boer, Th. A., 1990. Botanical characteristics of vegetation objects and their influence on remote sensing. (In Dutch). In: H. J. Buiten \& J. G. P. W. Clevers (Eds), Remote Sensing, Theorie en Toepassingen van Land-observatie, p. 73-84. Pudoc, Wageningen.

Epema, G. F., 1987. New information on second generation Landsat satellites for agricultural application in the Netherlands. Netherlands Journal of Agricultural Science 35: 497-504.

Janse, A. R. P., N. J. Bunnik \& J. P. Damen, 1976. Reflection spectra of several soil surfaces in the Netherlands. (In Dutch). Landbouwkundig Tijdschrift 88 (8): 7 pp.

Laan, F. B. van der, 1989. The chance of cloud free imagery of the Netherlands. Remote Sensing Newsletter No 38. Netherlands Remote Sensing Board (BCRS), Delft, 9 pp.

Mulders, M. A., 1987. Remote Sensing in Soil Science. Developments in Soil Science No 15. Elsevier Science Publishers, Amsterdam, $379 \mathrm{pp}$.

Paltridge, G. W. \& J. Barber, 1988. Monitoring grassland dryness and fire potential in Australia with NOAA/AVHRR data. Remote Sensing of Environment 25: 381-393.

Richardson, A. J., J. H. Everitt \& H. W. Gausman, 1983. Radiometric estimation of biomass and nitrogen content of Alicia grass. Remote Sensing of Environment 13: 179-184.

Stiboka, 1977. Soil Map of the Netherlands, Sheet No 12 East (Assen) with Explanation. Stichting voor Bodemkartering, Wageningen, $169 \mathrm{pp}$. 